\title{
AYURLOG
}

National Journal of Research in Ayurved Science

http://www.ayurlog.com

January-March: 2021| Volume: 09 ${ }^{\text {th }} \mid$ Issue:1 ${ }^{\text {st }}$

ISSN: $2320-7329$

\section{Review of evidence based study on Vyaghri Haritaki Avaleha with special reference to certain respiratory disorders.}

\section{Anju Sreedharan, Nilesh Suryawanshi}

1. PG Scholar,

2. Associate Professor and Guide, Email id - dr.nilsurya@gmail.com

Ras Shastra and Bhaishajya Kalpana Department, D.Y. PATIL deemed to be university school of Ayurveda,

Nerul, Navi Mumbai, Maharashtra

*Corresponding author: Email id - anju.sreedharan@gmail.com; 7999063872

\begin{abstract}
BACKGROUND

Respiratory disorders are leading cause of morbidity and mortality that induces an economic and social burden worldwide. In today's world, finding preventive methods and cure from these enormous challenges should be one of the priorities in the global health sector. Vyaghri haritaki avaleha is a potential Ayurveda polyherb formulation used for treating Kasa, Shwasa, Rajyakshma, Peenasa and its Rasayana properties ensures better quality of life of the patient.
\end{abstract}

\section{AIM AND OBJECTIVE}

Overview on Vyaghri haritaki avaleha

To conduct a review on evidence-based study of Vyaghri haritaki avaleha in the management of symptoms of respiratory disorders.

\section{METHODS}

To conduct this study, Ayurveda research articles were obtained from Google Scholar. Total 6 studies were yielded, which included only Clinical and Pre-Clinical studies.

\section{RESULT}

- Out of the 6 articles found $(n=6), 1$ article was an In-Vivo study and other 5 
articles were Clinical studies on Vyaghri haritaki avaleha.

- Among the 5 Clinical studies, 1 study was found to be a comparative analysis between Vyaghri haritaki avaleha and Ashtang avaleha.1 study was found, where Anu taila Nasya was used as an adjuvant along with Vyaghri haritaki avaleha.

- Out of the 5 Clinical studies on Vyaghri haritaki avaleha, 3 studies were conducted on children.

\section{CONCLUSION}

This review on Vyaghri haritaki avaleha provides a better understanding of this formulation and showcases its effectiveness in treating all types of Kasa roga, Tamaka shwasa, Chronic bronchitis and Dusht Pratishaya. This review throws light on extensive use of Vyaghri haritaki avaleha in children for treating the symptoms of respiratory disorders.

\section{KEYWORDS}

Vyaghri haritaki avaleha, In Vivo, Clinical study, Respiratory disorders, Immunomodulatory activity, Tamaka Shwasa, Chronic Bronchitis.

\section{INTRODUCTION}

Current outbreak of pandemic COVID 19 and the other pre-existing respiratory disorders are causing havoc to the respiratory health of the entire mankind across the globe. Prevention, control, cure of these diseases and promotion of respiratory health must be a top priority in global decision-making in the health sector. ${ }^{1}$

Ayurveda is a repository of innumerable formulations that have potential action on respiratory disorders. Ayurveda emphasizes on Prevention first and hence many Rasayana formulations are mentioned in various classical texts of Ayurveda. Rasayana formulations prevents diseases from becoming chronic and also accelerates the recovery. It enhances tissue strength by improving its functions and provides protection against diseases.

Vyaghri haritaki avaleha is an excellent polyherb formulation described in Chakradutt, Bhav Prakash, Yog Ratnakar, Bhaishajya Ratnawali under Kasarogadhikar Prakarnam and has been tilted as Rasayana by Acharya Bhrugu. It is indicated in Swasa, Kasa, Kshaya, Kshata, Peenasa, and Rajyakshma.

This formulation consists of two main ingredients Kantakari (Solanum xanthocarpum) and Haritaki (Terminalia 
chebula). Kantakari is known for its antiinflammatory, immunostimulatory, cough relieving properties and found to be very effective in controlling mild to moderate bronchial asthma. ${ }^{2,3}$ Haritaki is known for its Anti-oxidant, Free radical scavenging, Cytoprotective, Immuno-modulatory, Antiinflammatory and Anti-allergic activity. ${ }^{4}$ Trikatu an Chaturjat are the Prakshepa Dravya that helps in the bioavailability of the formulation. Trikatu also possesses immunomodulatory, antiviral, expectorant, carminative, hypolipidemic, hypoglycaemic, antiemetic, and anti-inflammatory potential. ${ }^{5}$ Chaturjat improves appetite, digestion and palatability of herbal formulations, also corrects respiratory and renal disorders. ${ }^{4}$ Guda has Shwashara, Kasahara properties and Madhu has Swasa, Kasa, Daahahar properties, and both increases the palatability of the formulation.

\section{METHOD OF PREPARATION OF VYAGHRI HARITAKI AVALEHA}

Table no. 1 Ingredients of Vyaghri haritaki avaleha

\begin{tabular}{|l|l|l|l|}
\hline SANSKRIT NAME & $\begin{array}{l}\text { BOTANICAL } \\
\text { NAME }\end{array}$ & PARTS USED & QUANTITY API \\
\hline KANTKARI & $\begin{array}{l}\text { Solanum } \\
\text { xanthocarpum }\end{array}$ & Whole plant & \\
\hline HARITAKI & Terminalia chebula & Fruit & $4.8 \mathrm{~kg}$ \\
\hline SHUNTHI & Zingiber officinalis & Rhizome & 100 in no. \\
\hline PIPPALI & Piper longum & Fruit & $96 \mathrm{gm}$ \\
\hline MARICHA & Piper nigrum & Fruit & $96 \mathrm{gm}$ \\
\hline TWAK & $\begin{array}{l}\text { Cinnamomum } \\
\text { zeylanicum }\end{array}$ & Stem Bark & $96 \mathrm{gm}$ \\
\hline ELA & $\begin{array}{l}\text { Elettaria } \\
\text { cardamomum }\end{array}$ & $48 \mathrm{gm}$ \\
\hline TEJPATRA & Cinnamomum tamala & Leaf & $48 \mathrm{gm}$ \\
\hline NAGKESAR & Mesua ferrea & Stamen & $48 \mathrm{gm}$ \\
\hline GUDA & - & - & 12.288 litres \\
\hline MADHU & - & - & $288 \mathrm{gm}$ \\
\hline
\end{tabular}


- Kwath dravya- Kantakari Panchang, Seedless Haritaki and Water.

- Madhur dravya- Guda.

- Prakshepa dravya- Madhu, Trikatu, Chaturjat.

Figure no. 1 Flow chart of Vyaghri haritaki avaleha preparation.

Water is taken in a clean vessel into which Kantakari

Panchang and Potalli containing seedless Haritaki is added and heated till it reduces to $1 / 8^{\text {th }}$ for the decoction.

The Pottali containing Haritaki is removed from the decoction and then strained.

1.Guda is added to the decoction and is heated till Paka lakshana attains.

After the Paka lakshana, Haritaki is added and mixed well.

The mixture is allowed to cool followed by which

Prakshepa Dravyas; Trikatu, Chaturjat and Honey is added and mixed homogeneously. Store the avaleha in a clean air tight glass container.

*Haritaki, after removing from the decoction can also be grinded into a smooth paste and then added to the Guda \& Kwath mixture for easy consumption.

Table no. 2 Ras Panchak of Vyaghri Haritaki Avaleha Ingredients

\begin{tabular}{|l|l|l|l|l|}
\hline Dravya & Rasa & Guna & Veerya & Vipaka \\
\hline Kantakari & Katu, Tikta & Laghu, Rooksha & Ushna & Katu \\
\hline Haritaki & $\begin{array}{l}\text { Madhur, Amla, } \\
\text { Katu, Tikta, } \\
\text { Kashaya }\end{array}$ & & Ushna & Madhur \\
\hline
\end{tabular}




\begin{tabular}{|l|l|l|l|l|}
\hline Shunthi & Katu & Laghu, Snigdha & Ushna & Madhur \\
\hline Maricha & Katu, Tikta & $\begin{array}{l}\text { Laghu,Rooksha, } \\
\text { Tikshana }\end{array}$ & Ushna & Katu \\
\hline Pippali & $\begin{array}{l}\text { Katu, Madhur, } \\
\text { Tikta }\end{array}$ & $\begin{array}{l}\text { Laghu, Snigdha } \\
\text { Katu, Tikta, } \\
\text { Twak }\end{array}$ & $\begin{array}{l}\text { Laghu, Rooksha, } \\
\text { Tikshana }\end{array}$ & Ushna \\
\hline Ela & Katu, Madhur & Laghu & Katu \\
\hline Tejpatra & Madhur, Katu & $\begin{array}{l}\text { Laghu, Picchila, } \\
\text { Tikshana }\end{array}$ & Ushna & Katu \\
\hline Nagkesar & $\begin{array}{l}\text { Katu, } \\
\text { Kashaya,Tikta }\end{array}$ & $\begin{array}{l}\text { Rooksha, Laghu } \\
\text { Ushna }\end{array}$ & Katu \\
\hline Guda & Madhur & $\begin{array}{l}\text { Laghu, } \\
\text { Ishatkshariya }\end{array}$ & NatiSheeta & Madhur \\
\hline Madhu & Madhur, Kshaya & $\begin{array}{l}\text { Ruksha, Laghu, } \\
\text { Sukshma }\end{array}$ & Sheeta & Katu \\
\hline
\end{tabular}

\section{METHODOLOGY}

This study aims to provide a review on evidence based studies for the assessment of Vyaghri haritaki avaleha in certain respiratory disorders. For this study, a review of Pre-Clinical and Clinical studies evaluating the efficacy of Vyaghri haritaki avaleha in the management for treating certain respiratory disorders was carried out. This was done with help of Ayurveda Journals in Google Scholar.

Keywords used for the purpose of this review included were Vyaghri haritaki avaleha, In Vivo, Clinical study, Respiratory disorders, Immunomodulatory activity, Tamaka Shwasa, Chronic Bronchitis.
RESULT: Out of the 6 articles found $(\mathrm{n}=6)$, 1 article was an In-Vivo Immunomodulatory study of Vyaghri haritaki avaleha and other 5 articles were Clinical studies on Vyaghri haritaki avaleha.

- Among the 5 Clinical studies, 1 study was found to be a comparative analysis between Vyaghri haritaki avaleha and Ashtang avaleha; 1 study was found where Anu taila Nasya was used as an adjuvant along with Vyaghri haritaki avaleha.

- Out of the 5 Clinical studies on Vyaghri haritaki avaleha, 3 studies were conducted on children.

- Among the 5 Clinical studies, 2 studies on Kasa, 1 study on Chronic Bronchitis, 1 study on Tamaka shwasa and 1 study on Dusht Pratishaya were found. 
Table no. 3- CHARACTERISTICS, METHODOLOGY AND OUTCOMES OF STUDIES

\begin{tabular}{|c|c|c|c|c|}
\hline $\begin{array}{l}\text { AUTHORS } \\
\text { PUBLICATIONS } \\
\text { YOP }\end{array}$ & \begin{tabular}{|ll} 
TYPE & OF \\
STUDY &
\end{tabular} & $\begin{array}{l}\text { STUDY } \\
\text { MODEL }\end{array}$ & DOSES & OUTCOMES \\
\hline $\begin{array}{l}\text { Roshy Joseph C, } \\
\text { Ilaanchezhian R, } \\
\text { Ashok B.K et.al }\end{array}$ & In -Vivo study & $\begin{array}{l}\text { Wister strain } \\
\text { albino rats of } \\
\text { either sex }\end{array}$ & $\begin{array}{l}1.8 \mathrm{gm} / \mathrm{kg} \text { of } \\
\text { VHA for rats }\end{array}$ & $\begin{array}{l}\text { VHA showcasec } \\
\text { enhanced antibody titre } \\
\text { indicating the presence } \\
\text { of moderate } \\
\text { immunostimulant } \\
\text { activity. } \\
\text { Significant decrease in } \\
\text { eosinophil anc } \\
\text { Monocyte counts in } \\
\text { SRBC control group was } \\
\text { noted. } \\
\text { Histopathological } \\
\text { observation of this organ } \\
\text { shows increasec } \\
\text { cellularity in the treated } \\
\text { group. }\end{array}$ \\
\hline $\begin{array}{l}\text { Dr Deepshikha, } \\
\text { Dr B.M. Singh, } \\
\text { Dr P.S. Upadhyay } \\
8 \\
\text { World Journal of } \\
\text { Pharmaceutical } \\
\text { Research, } 2015 .\end{array}$ & $\begin{array}{l}\text { Single } \\
\text { Trial }\end{array}$ & $\begin{array}{l}\text { No. } \\
\text { children }=49 \\
\text { Age group }=1 \\
\text { to } 12 \mathrm{yrs}\end{array}$ & $\begin{array}{l}150 \mathrm{mg} / \mathrm{kg} / \mathrm{dose} \\
\text { every } 6 \text { hour, } \\
\text { orally for seven } \\
\text { days }\end{array}$ & $\begin{array}{l}\text { VHA is found to be } \\
\text { more effective by } \\
\text { subsiding- Peenasa } \\
\text { Ghana kapha \& white } \\
\text { sputum in Kaphaja Kasa } \\
\text { Highly significant in } \\
\text { subsiding Mukha-kantha } \\
\text { shushkta, shushka kasa } \\
\text { in Vataja cases. } \\
\text { Highly significant result } \\
\text { in Kanth-kandu, Pitta } \\
\text { Nishthivan of Pittaja } \\
\text { kasa } \\
\text { VHA is effective in al } \\
\text { three types of Kasa i.e } \\
\text { Vataja, Pittaja and }\end{array}$ \\
\hline
\end{tabular}




\begin{tabular}{|c|c|c|c|c|}
\hline & & & & $\begin{array}{l}\text { Kaphaja kasa but has } \\
\text { better effect in Vatika } \\
\text { kasa. }\end{array}$ \\
\hline $\begin{array}{l}\text { Suhas } \\
\text { Chaudhary, Patel } \\
\text { KS, Kori VK, } \\
\text { et.al } 9 \\
\text { Ayurpharm - } \\
\text { International } \\
\text { Journal } \\
\text { Ayurveda and } \\
\text { Allied } \\
\text { Sciences,2014 }\end{array}$ & $\begin{array}{l}\text { Randomized } \\
\text { open ended } \\
\text { Clinical Trial }\end{array}$ & $\begin{array}{l}\text { No. of } \\
\text { children=23 } \\
\text { Age group=3 } \\
\text { to12yrs }\end{array}$ & $\begin{array}{l}8 \mathrm{gm}-15 \mathrm{gm} \text { of } \\
\text { VHA as per } \\
\text { age (divided } \\
\text { into } 2 \text { doses) } \\
\text { for } 4 \text { weeks }\end{array}$ & 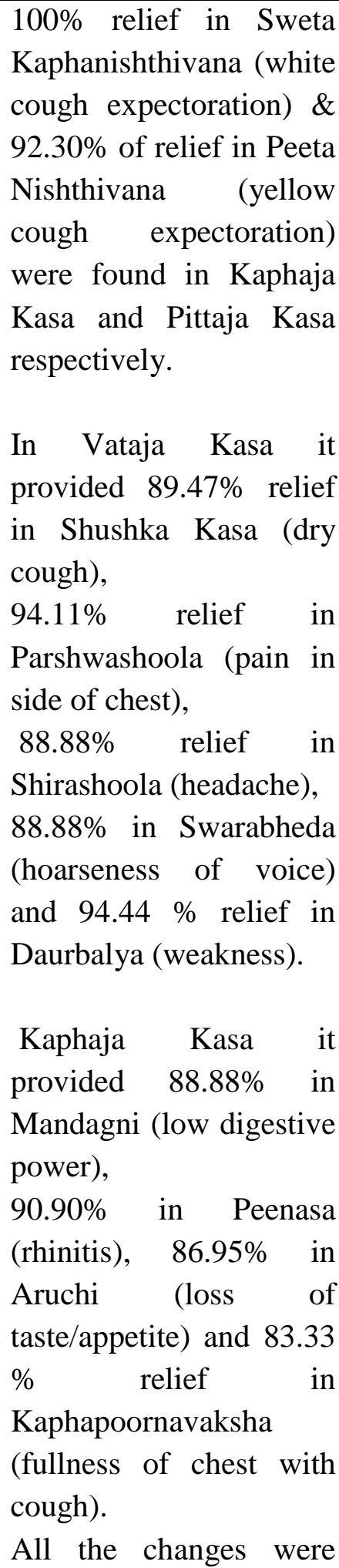 \\
\hline
\end{tabular}




\begin{tabular}{|c|c|c|c|c|}
\hline & & & & $\begin{array}{l}\text { statistically } \quad \text { highly } \\
\text { significant. }\end{array}$ \\
\hline $\begin{array}{l}\text { Jaiprakash Ram } \\
\text { M.S. Baghel. }{ }^{10} \\
\text { AYU } 2015\end{array}$ & $\begin{array}{l}\text { Single Arm } \\
\text { Trial }\end{array}$ & $\begin{array}{l}\text { No. of } \\
\text { patients }=66 \\
\text { Age group } \\
=16-70 y r s\end{array}$ & $\begin{array}{l}10 \text { gm of VHA } \\
\text { twice a day } \\
\text { with lukewarm } \\
\text { water before } \\
\text { meals for } 12 \\
\text { weeks }\end{array}$ & $\begin{array}{l}\text { Wheezing, Chest pain } \\
\text { and Sore throat- } 100 \% \\
\text { result was found, } \\
\text { Nasal congestion- } \\
97.62 \% \quad \text { relief, } \\
\text { Dyspnoea- } 83.3 \% \text { relief } \\
\text { and } \\
68.9 \% \quad \text { relief in } \\
\text { productive cough. This } \\
\text { improvement is } \\
\text { statistically } \\
\text { significant }(P<0.001)\end{array}$ \\
\hline $\begin{array}{l}\text { Arvind Kumar } \\
\text { Dubey, } \\
\text { S. Rajagopal, et } \\
\text { al. } \\
\text { AYU } 2014\end{array}$ & $\begin{array}{l}\text { Randomized } \\
\text { Clinical Trial } \\
\text { Comparative } \\
\text { study between } \\
\text { two Ayurvedic } \\
\text { Formulation } \\
\text { Ashtanga } \\
\text { Avaleha and } \\
\text { Vyaghri } \\
\text { haritaki } \\
\text { Avaleha } \\
\text { in Children }\end{array}$ & $\begin{array}{l}\text { Total no. of } \\
\text { children }=100 \\
\text { Age group: } \\
2-16 y r s\end{array}$ & $\begin{array}{l}\text { 5-15gm of } \\
\text { VHA and } \\
\text { Ashtanga } \\
\text { avaleha in } \\
\text { divided doses } \\
\text { for } 8 \text { weeks }\end{array}$ & $\begin{array}{l}\text { Marginal better efficacy } \\
\text { of Ashtanga Avaleha } \\
(66.66 \%) \text { in comparison } \\
\text { to Vyaghri Haritaki } \\
\text { Avaleha }(63.15 \%) \text { on the } \\
\text { overall evaluation of the } \\
\text { patients. } \\
\text { Vyaghri Haritaki } \\
\text { Avaleha more significant } \\
\text { (<0.01) in reducing Kasa } \\
\text { than Ashtanga Avaleha. }\end{array}$ \\
\hline $\begin{array}{l}\text { Parth P Dave, } \\
\text { Kunjal H Bhatta, } \\
\text { Vaghela DB, et.al } \\
12 \\
\text { International } \\
\text { Journal of } \\
\text { Ayurvedic } \\
\text { Medicine, } 2016\end{array}$ & $\begin{array}{l}\text { Multi Arm } \\
\text { Trial } \\
\text { Study of two } \\
\text { Ayurveda } \\
\text { management: } \\
\text { Vyaghri } \\
\text { haritaki } \\
\text { avaleha along } \\
\text { with Anu taila } \\
\text { Nasya \&only }\end{array}$ & $\begin{array}{l}\text { Total no. of } \\
\text { Patients }=30 \\
\text { Age group: } \\
12-70 y r s\end{array}$ & $\begin{array}{l}\text { Oral. Dose: } 5 \text { - } \\
\text { 10gm of } \\
\text { VHA/Two } \\
\text { times a day } \\
\text { after food with } \\
\text { luke warm } \\
\text { water for } 2 \\
\text { months. } \\
\text { Anutaila Nasya } \\
\text { Drug. Route of } \\
\text { Administration: }\end{array}$ & $\begin{array}{l}\text { Group A (VHA \&Anu } \\
\text { taila nasya)- Nasasrava } \\
\text { reduced in } 80.77 \% \\
\text { patients while in Group } \\
\text { B (only VHA) it reduced } \\
\text { in } 88.22 \% \text { patients } \\
\text { Nasaavarodha was } \\
\text { reduced in } 66.46 \% \\
\text { patients in Group A, } \\
\text { while } 84.21 \% \text { patients } \\
\text { in Group B. }\end{array}$ \\
\hline
\end{tabular}




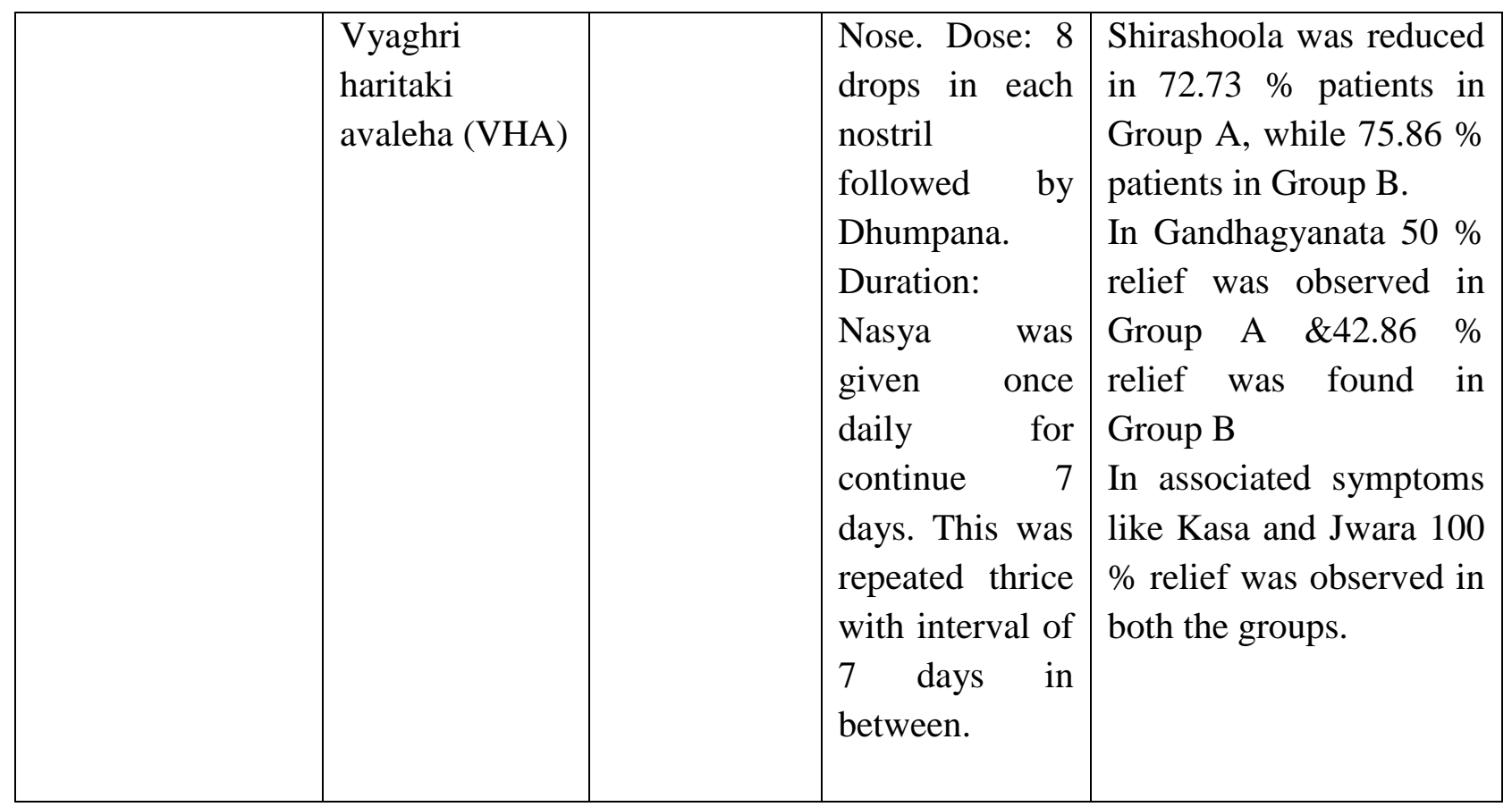

*VHA- Vyaghri haritaki avaleha

\section{DISCUSSION}

This study aimed to conduct an evidencebased review for the assessment of Vyaghri haritaki avaleha on certain respiratory disorders. This formulation was selected because of its Kasa, Shwashara activity along with Rasayana properties. In this study the, In vivo study of Immunomodulatory activity of this formulation provided enhanced antibody titre indicating the presence of moderate immunostimulant activity hence scientifically supporting the Rasayana effect of Vyaghri haritaki avaleha.

The two studies on Kasa roga in children showcased highly significant results in subsiding major symptoms like Kaphanishthivana (white cough expectoration) \& Peeta Nishthivana (yellow cough expectoration) found in Kaphaja Kasa and Pittaja Kasa respectively, Daurbalya (weakness), Mukha-kantha shushkta, shushka kasa in Vataja cases, and Kanthkandu.

Chronic bronchitis study of Vyaghri haritaki avaleha also proved to be highly significant in improving the major symptoms like Wheezing, Chest pain and Sore throat (100\% result), Nasal congestion (97.62\% relief), Dyspnoea (83.3\% relief) and $68.9 \%$ relief in productive cough.

In the Comparative study between Ashtanga Avaleha and Vyaghri haritaki Avaleha in Children for treating Tamaka Shwasa exhibits marginal efficacy between the two formulations Ashtanga Avaleha (66.66\%) \& Vyaghri Haritaki Avaleha (63.15\%) on the overall evaluation of the patients.

The effect of Vyaghri haritaki avaleha on treating Dusht Pratishaya along with Anu Taila has also proved to be beneficial in significantly reducing the symptoms of 
Nasasrava, Nasaavrodha, Shirashool and Gandha agyanta.

\section{STRENGTH AND LIMITATIONS}

This kind of study helps to determine the potential of drugs in treating various diseases. During this study, very few Clinical and only one Pre-clinical articles were found on Vyaghri haritaki avaleha. Hence, a systematic review on the same could not be done.

\section{REFERENCES}

1. The Global Impact of Respiratory Disease - Second Edition Forum of International Respiratory Societies Print ISBN: 9781849840873; eISBN: 9781849840880 Cite this publication as: Forum of International Respiratory Societies. The Global Impact of Respiratory Disease - Second Edition. Sheffi eld, European Respiratory Society, 2017.

2. Deepshikha et al: Vyaghri Haritaki: A Drug Overview IJAAR VOLUME II ISSUE IV NOV-DEC 2015

3. Dr Jaiprakash, Baghel M. S, ShuklaV.J. Standardization of polyherb ayurvedic formulation Vyaghri haritaki avaleha with classical view point. International Research Journal of Pharmacy.2012 April;3(4):226-230

4. Anwesa Bag et al. Therapeutic potential of Terminalia chebula Retz. (Combretaceae): The Ayurvedic Wonder. Asian Pac J Trop Biomed 2013; 3(3): 244-252
5. Trikatu - A combination of three bioavailability enhancers Rahul Kaushik et al.

International Journal of Green Pharmacy • July-Sep 2018 (Suppl) • $12(3)$

6. Bharat Jhanwar1*, Renu Solanki1, Manjeet Singh2Journal of Pharmacognosy and Phytochemistry Determination of Quality Standards for Herbal Formulation: Chaturjat Churna Volume 2 Issue 1 Vol. 2 No. 12013

7. Roshy Joseph C, Ilanchezhian R, Ashok BK, Biswajyoti Patgiri, Ravishankar B. Immunomodulatory activity of Vyaghriharitaki avaleha on humoral anti-body formation. Ayurpharm Int $\mathrm{J}$ Ayur Alli Sci. 2014;3(3):52-60.

8. Dr Deepshikha1, Dr.B.M.Singh, Dr.P.S.Upadhyay. EVALUATION OF VYAGHRI HARITAKI IN MANAGEMENT OF KASASHWASA OF CHILDREN" World Journal of Pharmaceutical ResearchVol 4, Issue 5, 2015.

9. Suhas A. Chaudhary, Patel KS, Kori VK, Rajagopala S. Management of doshika kasa in subacute and chronic stage with Vyaghri haritaki avaleha in children. Ayurpharm Int J Ayur Alli Sci. 2014;3(4):97-111.

10. Jaiprakash Ram, Madhav Singh Baghel. Clinical efficacy of Vyaghri haritaki avaleha in the management of Chronic Bronchitis. Ayu 2015;36:50-5.

11. Dubey AK, Rajagopal S, Patel KS. Comparative clinical efficacy of Ashtangavaleha and Vyaghri haritaki avaleha on Tamaka Shwasa in children.AYU JOURNAL 2014; 
35(4): 384-390.DOI: $10.4103 / 097-$ 8520.158995 .

12. Parth P Dave*, Kunjal H Bhatta, Vaghela DB , Dhiman KS.Role of Vyaghri Haritaki Avaleha and Anu Taila Nasya in the management of Dushta Pratishyaya (Chronic Sinusitis) International Journal of Ayurvedic Medicine, 2016, 7(1), 4955

13. Govindan S, Viswanathan S, Vijayasekaran V, Alagappan R. Further studies on the clinical efficacy of Solanum xanthocarpum and Solanum trilobatum in bronchial asthma. Phytother Res 2004;18:805-9.
14. Sultana R, Khanam S, Devi K. Evaluation of immunomodulatory activity of Solanum xanthocarpum fruits aqueous extract. Pharm Lett 2011;3:247-53.

15. Aher V, Wahi AK. Immunomodulatory activity of alcohol extract of Terminalia Chebula Retz. Combretaceae. Trop J Pharm Res 2011;10:567-75.

16. Gupta A, Prajapati PK. Effect of different Avaleha in the management of Tamaka Shwasa. AYU JOURNAL 2011;32(3): 427-430.DOI: $10.4103 / 0974-8520.93928$.

Conflict of Interest: Non

Source of funding: Nil

Cite this article:

"Review of evidence based study on Vyaghri Haritaki Avaleha

with special reference to certain respiratory disorders."

Anju Sreedharan, Nilesh Suryawanshi

Ayurlog: National Journal of Research in Ayurved Science- 2021; (09) (01):01- 11

11 | January-March: 2021| Volume: 09th | Issue:1 ${ }^{\text {st }}$

E- ISSN: 2320-7329 